\title{
STUDIES IN CONGESTIVE HEART FAILURE
}

\author{
IV. The Potassium Content of Skeletal and Cardiac Muscle \\ By TINSLEY RANDOLPH HARRISON, COBB PILCHER AND GEORGE EWING \\ (From the Department of Medicine, Vanderbilt University School of Medicine, \\ Nashville, Tenn.)
}

(Received for publication July 12,1929 )

\section{INTRODUCTION}

Observations concerning the gas exchange during and after exercise of patients with congestive cardiac failure indicated that such individuals had an impaired capacity to accumulate a large oxygen debt (Harrison and Pilcher, 1930b). This finding suggested that the total buffering power of the tissues was diminished. Studies of carbon dioxide excretion led to the belief that the non-carbonate, rather than the carbonate, buffers were affected.

In subsequent studies (Pilcher, Clark and Harrison, 1930) it was found that the addition of an acid to the blood stream (by exercise, by administration of ammonium chloride or by inhalation of carbon dioxide) was sometimes followed by a greater change in hydrogen ion concentration in patients with congestive heart failure than in normal individuals. This was regarded as compatible with the hypothesis of diminished tissue buffering power in heart failure.

All of the changes which have been mentioned were absent in patients who had never had edema. Such changes as were found in "compensated" individuals could be explained by limitation of cardiac output. The findings interpreted as indicating decreased tissue buffers were observed only in subjects who had edema at the time they were studied, or who had recently been edematous. Since similar findings were observed in individuals who had edema due to causes other than disease of the heart, it was concluded that edema per se was a factor in causing tissue acidosis, the term being used to mean decreased 
reserve alkali. Such a conclusion was in accord with the observation of Harrison and Pilcher (1930a) that edema caused decreased utilization of oxygen in the tissues and,- by analogy to pulmonary edemaapparently led to diminished tissue oxygen tension.

It has been thought that "tissue acidosis" was an important factor in the production of the symptoms of congestive heart failure and although the findings obtained with the several different methods of study were compatible with each other it has seemed that a more direct approach to the problem would be of value. Decreased buffering power, if present, might be due to (1) increase in acid bodies, (2) diminution of alkaline substances, or (3) both of these phenomena. As the acid substances in tissues are subject to rapid postmortem changes, it was thought that a study of the tissue chemistry had best-for the time being - be confined to the bases. One of the most abundant basic substances in skeletal and cardiac muscle is potassium; the muscle content of this element has therefore been investigated.

\section{METHOD}

The tissues were obtained at the postmortem table. Small pieces (about two grams in weight) of skeletal and cardiac muscle were dissected free of tendon and fat, care being taken not to squeeze the specimen. The tissue was immediately weighed in a small weighing bottle and then heated at $100^{\circ}$ to $110^{\circ}$ in a drying oven for three days or longer. When constant weight has been obtained the dried muscle was cut with sharp scissors and duplicate analyses were performed on fractions weighing one to two decigrams.

After several methods of analysis had been found unsatisfactory the following technique was adopted. Digestion was carried out as advised by Van Slyke for chlorides (1923). The piece of dried muscle was put in a 75 cc. pyrex test tube. Three cubic centimeters of concentrated nitric acid were added. The tube was then covered with a funnel, the smaller end of which had been sealed in a flame, and heated overnight in a steam bath. After digestion had proceeded for sixteen hours or longer the funnel was removed, and the contents of the tube were evaporated to dryness in the steam bath. In order to eliminate all ammonia, three cubic centimeters of normal sodium hydroxide were added and the evaporation to dryness was repeated. 
Two cubic centimeters of distilled water and three cubic centimeters of normal sulphuric acid were added. The brownish liquid was now stirred and one cubic centimeter-representing one fifth of the original piece of dry muscle-was taken for precipitation with the cobaltinitrite reagent of Kramer and Tisdall (1921). The subsequent washing and centrifuging was carried out according to their method with these exceptions: instead of pipetting off the supernatant fluid we decanted it after each centrifugalization. We also found it convenient to break up the precipitate by a stream of fluid at each washing rather than to allow the fluid to flow down the side of the tube. After the third washing the technique of Kramer and Gittleman (1926) was followed, the potassium being determined gasometrically in the Van Slyke-Neill (1924) apparatus.

In the first analyses duplicate determinations from the same tissue varied as much as fifteen per cent. After we had become more experienced in the method agreement within five per cent was usually obtained. It is felt that the values found are accurate relative to each other and in any case the difference between edematous and non-edematous muscles are so great as to be well beyond the limits of error of the method used.

In most of the subjects analyses were made of the two ventricles and of gastrocnemius muscle, but in several instances other skeletal muscles were also analyzed.

The terms "wet muscle" and "dry muscle" are used in this paper to designate the specimens before and after drying, respectively. The "percentage solid" is obtained by dividing the weight of the dry muscle by that of the wet muscle. By dividing the percentage of potassium in dry muscle (obtained by analysis) by the percentage solid, and multiplying by 100 , the percentage of potassium in the wet muscle was obtained.

Tissues from four patients who had congestive cardiac failure were studied. Of these, two (F. H. and J. R.) had hypertensive heart disease, one (R.R.) had syphilitic aortic insufficiency, and the fourth (E. H.) had rheumatic heart disease with chronic mitral endocarditis. One individual (M. M.) had edema not due to heart disease and the remaining two subjects (O. F. and R.D.) died without edema and without heart disease. More complete data in regard to the patients are presented in the tables. 


\section{RESULTS}

The analyses of the tissues from the "control" subjects-those without edema-are shown in table 1, and those of the tissues from edematous individuals are presented in table 2 . In both of the patients in table 1 the total solid content was greatest in the gastrocnemius muscle, least in the right ventricle, and intermediate in the left ventricle. The potassium content of the two ventricles was approximately the same, but was less than that of the skeletal muscle. The average values for the two subjects were 0.270 and 0.395 per

TABLE 1

The solids and potassium content of the cardiac and skeletal muscle of individuals with no edema and with no cardiac disease

\begin{tabular}{|c|c|c|c|c|c|c|c|c|c|c|}
\hline \multirow[b]{2}{*}{ Subject } & \multirow[b]{2}{*}{ Diagnosis } & \multicolumn{3}{|c|}{ Right ventricle } & \multicolumn{3}{|c|}{ Left ventricle } & \multicolumn{3}{|c|}{ Skeletal muscle of leg } \\
\hline & & $\begin{array}{l}\text { Total } \\
\text { solids }\end{array}$ & $\begin{array}{l}\text { Potas- } \\
\text { sium } \\
\text { in dry } \\
\text { muscle }\end{array}$ & $\begin{array}{l}\text { Potas- } \\
\text { sium } \\
\text { in wet } \\
\text { muscle }\end{array}$ & $\begin{array}{l}\text { Total } \\
\text { solids }\end{array}$ & $\begin{array}{l}\text { Potas- } \\
\text { sium } \\
\text { in dry } \\
\text { muscles }\end{array}$ & $\begin{array}{l}\text { Potas- } \\
\text { sium } \\
\text { in wet } \\
\text { muscles }\end{array}$ & $\begin{array}{l}\text { Total } \\
\text { solids }\end{array}$ & $\begin{array}{c}\text { Potas- } \\
\text { sium } \\
\text { in dry } \\
\text { mus- } \\
\text { cles }\end{array}$ & $\begin{array}{l}\text { Potas- } \\
\text { sium } \\
\text { in wet } \\
\text { muscles }\end{array}$ \\
\hline \multirow{3}{*}{ R. D. } & \multirow{4}{*}{ Tumor of brain } & per cent & per cent & per cent & per cent & per cent & per cent & $\begin{array}{l}\text { per } \\
\text { cent }\end{array}$ & $\begin{array}{l}\text { per } \\
\text { cent }\end{array}$ & per cent \\
\hline & & 20.4 & 1.41 & 0.288 & 22.4 & 1.22 & 0.273 & 26.7 & 1.12 & 0.298 \\
\hline & & 20.6 & 1.20 & 0.247 & 23.7 & 1.16 & 0.275 & 27.5 & 1.16 & 0.318 \\
\hline Average & & 20.5 & 1.30 & 0.267 & 23.0 & 1.19 & 0.274 & 27.1 & 1.14 & 0.308 \\
\hline \multirow[t]{3}{*}{ O. F. } & \multirow{4}{*}{$\begin{array}{l}\text { Pulmonary } \\
\text { tuberculosis }\end{array}$} & 17.9 & 1.90 & 0.340 & 21.4 & 1.62 & 0.345 & 24.9 & 1.40 & 0.369 \\
\hline & & & 1.54 & 0.289 & & 1.36 & 0.291 & & 1.64 & 0.408 \\
\hline & & 18.7 & 1.58 & 0.283 & 21.3 & 1.34 & 0.285 & 26.4 & 1.45 & 0.383 \\
\hline Average & & 18.3 & 1.67 & 0.304 & 21.3 & 1.44 & 0.307 & 25.6 & 1.50 & 0.387 \\
\hline
\end{tabular}

cent for the wet heart muscle and 0.308 and 0.387 for the wet skeletal muscle. These values are of the same order of magnitude as those found for human tissue by Lematte, Boinot and Kahane (1928), (0.263 per cent skeletal muscle and 0.314 per cent for cardiac muscle) and agree very well with the findings of Norn (1929) (0.349 and 0.293 per cent for skeletal and.cardiac muscle, respectively). For this reason further control studies seemed unnecessary.

The values for total solids of the right ventricles of the patients dying of congestive heart failure were approximately the same as those of the controls. The solids of the left ventricles were all some- 
what less in the control subjects (average values were 19.9, 19.4 and 17.6 per cent as compared to 23.0 and 21.3 per cent in the "normals"). This phenomenon was still more striking in the leg muscles of three of the subjects with congestive failure. These individuals had 18.5, 14.6 and 16.3 per cent total solids, whereas, the control subjects had 27.1 and 25.6 per cent. The fourth subject with cardiac disease (F. H.) had an abnormally high percentage of total solids in the leg muscle (30.2). This may have been due to the fact that he had received "salyrgan" and had had copious diureses the day before he died.

The potssium content of the ventricular muscle was determined in three of the four patients with congestive heart failure. In each instance a marked diminution was found. This was not due to simple dilution from edema fluid, as the dried cardiac muscle of these subjects contained approximately thirty per cent less potassium than did that of the control subjects. The two subjects (J. R. and F. H.) who had had edema for the longest time, exhibited greater decrease of the cardiac potassium content than did the subject (E. H.) who had suffered for a shorter period.

The potassium content of the leg muscle was less in the four patients with congestive heart failure than in the subjects who died from other causes. The degree of diminution in the potassium of the wet muscle was more or less in proportion to the amount of edema at the time of death, and hence was partially dependent on dilution. This was not the sole factor, however, for F. H., whose skeletal muscle contained less water than that of the control subjects, had a lower potassium content than either of them.

The degree of decrease in the potassium content of the dry muscle from the leg was in proportion to the length of time the patient had been edematous rather than to the amount of edema at the time of death. The dry muscle potassium content of the control subjects was approximately the same for cardiac and skeletal muscle. The same relationship held true - at a lower level-in the two subjects who had had edema for a relatively long time. However, E. H., who had had edema for a much shorter time, had considerably less potassium in the dry muscle of the leg than in that of the heart.

Skeletal muscle from the arm was analyzed in two of the patients 


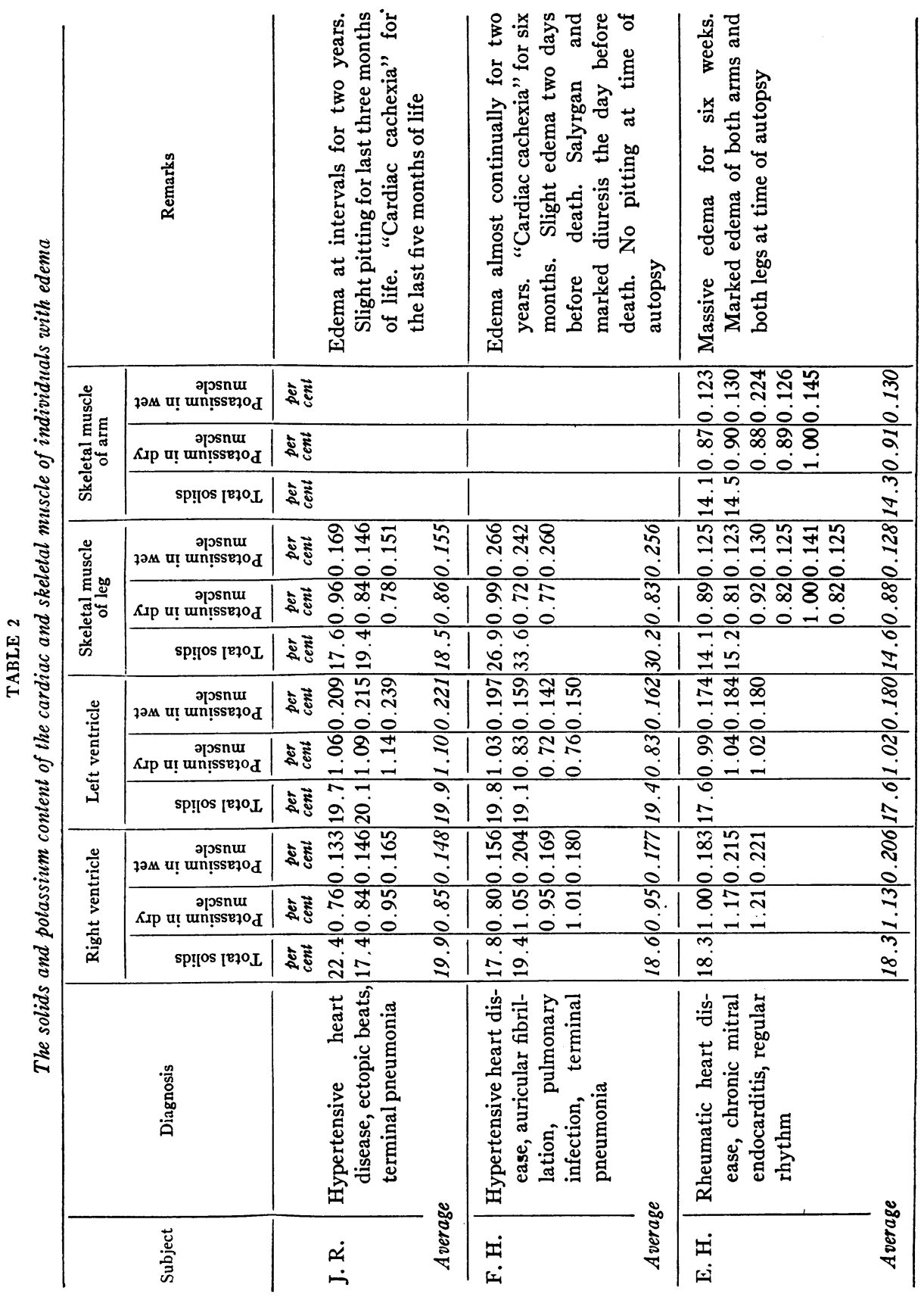




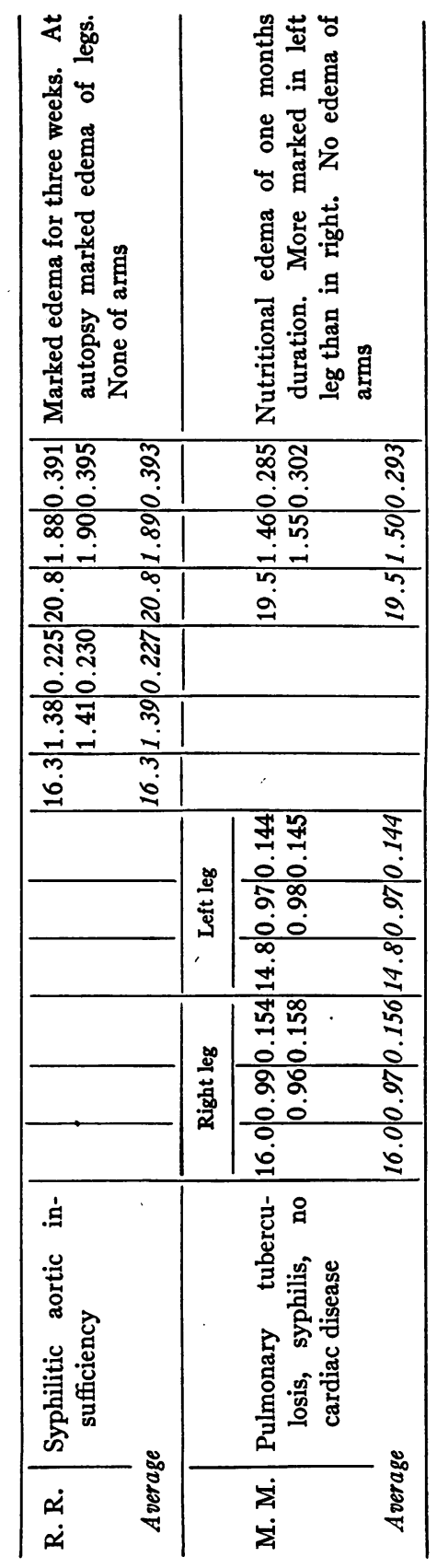


with heart disease. One of these (E. H.) had marked edema of the arms. The potassium content of the dried muscle of the arm was markedly reduced, being about the same as that of the equally edematous leg muscle. The other subject (R. R.) had no obvious edema of the arms. He had massive edema of his legs which had been present for three weeks. The wet muscle of the arm contained about eighty per cent more potassium than that of the leg, and the dry muscle of the arm about thirty per cent more than that of the leg.

The results which have been presented thus far appear to indicate that the diminution in potassium content is related to edema per se rather than to heart disease. In order to test this hypothesis, analyses were performed of the muscle of a subject (M. M.) who had edema but no disease of the heart. The edema was confined to the legs. The potassium content of the wet muscle of the arm was more than twice that of the legs. The dry muscle of the arm was richer by fifty per cent in potassium.

The following tentative premises appear to be justified by the facts that have been presented:

1. The potassium content of the cardiac and skeletal muscle of individuals dying with chronic congestive cardiac failure is diminished.

2. This diminution appears to be related directly to edema.

3. The degree of diminution of the potassium content of the dry muscle appears to be dependent on the duration rather than on the degree of edema at the time of death.

4. The first effect of edema in this respect appears to consist in a diminution of the potassium content of those muscles which are edematous. The potassium content of the non-edematous muscles may become diminished at a later date, possibly as a secondary compensatory phenomenon, but the data on this point are not conclusive.

\section{DISCUSSION}

The exact physico-chemical mechanism by which potassium is lost is not shown by our work, nor is the significance of the loss of potassium as a specific ion rather than as a basic substance.

The loss of potassium seems, however, to be in confirmation of the hypothesis of diminished tissue alkaline reserve mentioned in the introduction of this paper. It is possible that potassium lack is 
compensated by an increase in other basic substances, but this seems unlikely in view of our previously reported work (Harrison and Pilcher, 1930a and b; Pilcher, Clark and Harrison, 1930). Further study on this question is in progress.

The exact effects of loss of potassium cannot be definitely stated as yet. It is probable that it is accompanied by diminution in alkaline reserve of the heart muscle, as well as of skeletal muscle. Such a diminution may, as shown by Hill and his co-workers (1922) lead to "fatigue" of the muscle. Further, according to other investigators, notably Gremels and Starling (1926), Patterson (1915), Eppinger, Kisch and Schwarz (1927), and Takeuchi (1925), procedureswhich may tend to increase the acidity of the heart muscle cause dilatation of the heart. Indeed, Patterson, Piper and Starling (1914) suggested that cardiac fatigue resulted in dilatation of the heart for the performance of an amount of work previously done at a normal diastolic volume. Many writers (Osler (1919), Mackenzie (1925b), Krehl (1916), Vacquez (1924), MacCallum (1920)) believe dilatation to be an important cause of congestive heart failure. Hence, it seems possible that the loss of potassium, itself primarily a result of heart failure, may be an important factor in causing subsequent "breaks in compensation."

It is also possible that loss of potassium from skeletal muscle may be related to the clinically well recognized "cardiac asthenia" and weakness.

The findings reported here raise the question as to whether changes resulting in loss of potassium may not be reversed by the administration of potassium. Further work is in progress on this subject.

\section{SUMMARY}

1. The potassium content of the skeletal and cardiac muscle of individuals dying of congestive heart failure was found to be less than that of subjects dying without edema.

2. The potassium content per unit of dry weight of edematous muscle was less than that of non-edematous muscle. This was true whether the edema was due to heart disease or not.

3. The suggestion is offered that loss of potassium with consequent 
diminution in the buffering power of the heart muscle constitutes a physico-chemical factor in the production of "cardiac fatigue."

4. In patients with congestive cardiac failure the decrease in potassium is believed to have been originally an effect of heart failure, but is considered as probably a secondary but important cause of subsequent "breaks" in compensation.

\section{BIBLIOGRAPHY}

Christian, H. A., The Diagnosis and Treatment of Diseases of the Heart. Oxford Medical Monographs, p. 143, New York, 1928.

Eppinger, H., Kisch, F., and Schwarz, H., Das Versagen des Kreislaufes. Berlin, 1927.

Gremels, H., and Starling, E. H., J. Physiol., 1926, lxi, 297. On the Influence of Hydrogen Ion Concentration and of Anoxemia upon the Heart Volume.

Harrison, T. R., and Pilcher, C., (a) J. Clin. Invest., 1930, viii, 259. Studies in Congestive Heart Failure. I. The Effect of Edema on Oxygen Utilization.

Harrison, T. R., and Pilcher, C., (b) J. Clin. Invest., 1930, viii, 291. Studies in Congestive Heart Failure. II. The Respiratory Exchange during and after Exercise.

Harrison, T. R., Pilcher, C., and Ewing, G., J. Clin. Invest., 1930, viii, 317. Studies in Congestive Heart Failure. III. The Buffering Power of the Blood and Tissues.

Hill, A. V., and Lupton, H., Quart. J. Med., 1922-23, xvi, 135. Muscular Exercise, Lactic Acid and the Supply and Utilization of Oxygen.

Kramer, B., and Tisdall, F. F., J. Biol. Chem., 1921, xlvi, 339. A Clinical Method for the Quantitative Determination of Potassium in Small Amounts of Serum.

Kramer, B., and Gittleman, I., Proc. Soc. Exp. Biol. and Med., 1926, xxiv, 241. The Gasometric Determination of Potassium.

Krehl, L., The Basis of Symptoms. Third American Edition, p. 49, Philadelphia, 1916.

Lematte, L., Boinot, G., and Kahane, E., Bull. Soc. Chim. Biol., 1928, x, 553. La composition minérale des tissues de l'homme et des animaux.

MacCallum, W. G., A Text Book of Pathology. P. 467, Philadelphia, 1920.

MacKenzie, Sir James, (a) Diseases of the Heart. Fourth Edition, p. 33, Oxford, 1925.

MacKenzie, Sir James, Ibid., p. 311, 1925.

Norn, M., Scand. Arch. f. Physiol., 1929, lv, 162. Untersuchungen über das Verhalten des Kaliums im Organismus.

Osler, Sir William, Principles and Practice of Medicine. Eighth Edition, p. 820, New York, 1.919.

Patterson, S. W., Proc. Roy. Soc., Series, B., 1915, lxxxviii, 371. The Antagonistic Action of Carbon Dioxide and Adrenalin on the Heart. 
Patterson, S. W., Piper, H., and Starling, E. H., J. Physiol., 1914, xlviii, 465. The Regulation of the Heart Beat.

Starling, E. H., and Visscher, M. D., J. Physiol., 1927, '1xii, 243. The Regulation of the Energy Output of the Heart.

Takeuchi, K., J. Physiol., 1925, lx, 208. The Relation between the Size of the Heart and the Oxygen Content of the Arterial Blood.

Vacquez, H., Diseases of the Heart. Philadelphia, 1924, p. 29.

Van Slyke, D. D., J. Biol. Chem., 1923, lviii, 523. The Determination of Chlorides in Blood and Tissues.

Van Slyke, D. D. and Neill J. M., J. Biol. Chem., 1924, lxi, 523. Determination of Gases in Blood and Other Solutions by Vacuum Extraction and Manometric Measurement. 